\title{
DNA damage enhances integration of HIV-1 into macrophages by overcoming integrase inhibition
}

\author{
Takayoshi Koyama', Binlian Sun², Kenzo Tokunaga ${ }^{3}$, Masashi Tatsumi ${ }^{4}$ and Yukihito Ishizaka ${ }^{1 *}$
}

\begin{abstract}
Background: The prevention of persistent human immunodeficiency virus type 1 (HIV-1) infection requires the clarification of the mode of viral transduction into resting macrophages. Recently, DNA double-strand breaks (DSBs) were shown to enhance infection by D64A virus, which has a defective integrase catalytic activity (IN-CA). However, the mechanism by which DSBs upregulate viral transduction was unclear. Here we analyzed the roles of DSBs during IN-CA-independent viral transduction into macrophages.

Results: We used cellular systems with rare-cutting endonucleases and found that D64A virus integrated efficiently into the sites of artificially induced DSBs. This IN-CA-independent viral transduction was blocked by an inhibitor of ataxia telangiectasia mutated protein (ATM) but was resistant to raltegravir (RAL), an inhibitor of integrase activity during strand transfer. Moreover, Vpr, an accessory gene product of HIV-1, induced DSBs in resting macrophages and significantly enhanced the rate of IN-CA-independent viral transduction into macrophages with concomitant production of secondary viruses.

Conclusion: DSBs contribute to the IN-CA-independent viral infection of macrophages, which is resistant to RAL. Thus, the ATM-dependent cellular pathway and Vpr-induced DNA damage are novel targets for preventing persistent HIV-1 infection.
\end{abstract}

Keywords: DNA damage, HIV-1, Integrase inhibitor, Integration, Resting macrophages, Vpr

\section{Background}

The prognosis of individuals infected with human immunodeficiency virus type 1 (HIV-1) has improved due to the development of combination antiretroviral therapy (cART) [1]. However, several lines of evidence revealed that the current regimen does not block viral replication completely [2], which promotes the emergence of drug-resistant mutant viruses. Recently, new anti-retroviral drugs that target viral entry or the integration of viral DNA into the host genome have been applied clinically [3,4], which allows the possibility of overcoming viruses that are resistant to conventional cART. Moreover, an advanced study directed at the development of novel anti-HIV-1 compounds attempted to identify the cellular proteins that associate with HIV-1 proteins [5]. Macrophages are less sensitive to the toxic effects of HIV-1 and they function as persistent producers

\footnotetext{
* Correspondence: zakay@ri.ncgm.go.jp

'Department of Intractable Diseases, National Center for Global Health and Medicine, 1-21-1 Toyama, Shinjuku-ku, Tokyo 162-8655, Japan

Full list of author information is available at the end of the article
}

of the virus [2]; therefore, it is important to develop novel anti-HIV-1 compounds that target viral transduction into resting macrophages.

Integrase, a 288 -amino-acid and 32-kDa HIV-1 protein, promotes strand-transfer reaction [6], where the reversetranscribed double-stranded viral DNA is integrated into the host genome. The integrase catalytic activity (IN-CA) excises two nucleotides from the 3 -end of the viral DNA and the $\mathrm{CA}-3^{\prime}-\mathrm{OH}$ is ligated to the $5^{\prime}-\mathrm{O}$-phosphate end of the genomic DNA [6]. All these strand transfer steps depend on the presence of a D,D(35)E motif in the central domain and any mutations in this motif abrogate the activity required for the strand-transfer process [7]. Notably, single-strand gaps are produced in both regions flanking the viral DNA and it was postulated that cellular factors repair these gaps because viral proteins have a low DNA damage repair activity [8].

Initially, Daniel et al. proposed that DNA-dependent protein kinase was a cellular factor involved in gaprepair [9], and then ataxia telangiectasia mutated (ATM), ataxia telangiectasia and Rad3-related (ATR), Nijmegen

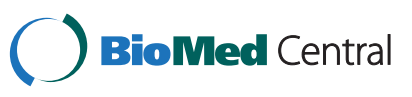


breakage syndrome 1 (NBS1), and poly(ADP-ribose) polymerase 1 (PARP1) have also been nominated as cellular proteins involved in efficient viral transduction [10-13]. Using KU55933, a specific ATM inhibitor, Lau et al. proposed that ATM is also involved in HIV-1 transduction [14], whereas Sakurai et al. demonstrated that DNA damage repair enzymes are involved in multiple steps of retroviral infection [15]. These observations support the importance of DNA double-strand breaks (DSBs) in viral transduction, although their roles are controversial [16-19]. A possible explanation for discrepancies in reported observations is that the single-strand gaps are repaired in a redundant fashion by DNA damage repair enzymes, the expression of which varies among cells [20]. It is also possible that DSBs have modest effects on viral transduction, which may be overwhelmed by the infectivity of the wild-type (WT) virus. This suggests that it is important to evaluate the effects of DSBs using more sophisticated experimental approaches.

Here we focused on the role of DNA damage (DSBs), particularly in integration of viral DNA. Interestingly, HIV-1 DNA integrated into artificially induced DSBs in an IN-CA-independent manner and DNA damaging agents upregulated the infectivity of IN-CA-defective virus. The positive effects of DSBs on viral integration were resistant to raltegravir (RAL), an IN-CA inhibitor. Moreover, Vpr, an accessory gene product of HIV-1, mimicked DNA damaging agents and increased INCA-independent viral transduction into monocytederived macrophages (MDMs). Even when the catalytic activity of IN was impaired, infectious secondary virus was generated without any mutations that yielded phenotypes resistant to RAL.

Based on these observations, we propose that the ATM-dependent mode of DSB-specific integration of viral DNA and the Vpr-induced DSBs are novel targets for anti-HIV compounds that inhibit viral transduction into MDMs, a persistent reservoir of HIV-1 infection.

\section{Results}

HIV-1 integrates into the sites of artificially induced DSBs

To understand the roles of DSBs in integration of viral DNA into macrophages, we established a system using THP-1 cells, a human monocytic leukemia cell line that differentiates into macrophage-like cells after treatment with phorbol myristate acetate (PMA) (Figure 1A) [21]. We transfected THP-1 cells with plasmid DNA that contained the recognition sequence for I-SceI, a rarecutting endonuclease [22] and obtained clones with the I-SceI site after drug selection. Using the experimental procedures outlined in Figure 1A, the frequency of viral DNA integration into I-SceI sites was evaluated. After PMA-treated cells were infected with VSVG-pseudotyped
WT virus (NL-Luc-E(-)R(-)) together with adenovirusexpressing I-SceI, provirus DNA was detected in the I-SceI provirus (Ad-I-SceI) site or its vicinity (Figure 1B, Additional file 1: Figure S1A). PCR amplification targeting the junction of the I-SceI site and the $5^{\prime}$-end of the integrated proviral DNA (Figure 1A) selectively generated PCR amplicons from the Ad-I-SceI-infected samples (compare the upper and lower panels of Figure 1B). Sequence analysis of several independent clones detected the presence of provirus DNA in the I-SceI site (Figure 1C, each arrowhead indicates the integration site of individual clones analyzed). Notably, KU55933 blocked I-SceI sitetargeted integration (Figure 1D, lower panel) [14].

Similar results were obtained using a different system with another rare-cutting endonuclease, I-PpoI (Figures 1$\mathrm{E}-\mathrm{H}$ and Additional file 1: Figure $\mathrm{S1B}$ ). The recognition sites of I-PpoI are present in the human genome, although the mammalian genome has no gene that encodes the enzyme [23]. In this experiment, we used a lentiviral vector to ensure the generality of our observations (Figure 1E). As shown in Figure 1F, the viral DNA reproducibly integrated into the I-PpoI site, which was confirmed by PCR amplification and sequence analysis (Figure $1 \mathrm{G}$ and $\mathrm{H}$ ). The data clearly indicated that the viral DNA was inserted in the DSB sites.

\section{Integration into DSB sites was independent of the catalytic activity of integrase}

Interestingly, analysis of the nucleotide sequence of the viral DNA inserted in the I-SceI site revealed that both the $5^{\prime}$ - and $3^{\prime}$-long terminal repeat (LTR) ends of the provirus DNA had adenine and cytidine (pAC) dinucleotides (Figure 1I) [6], suggesting that the viral DNA integrated into DSBs in an IN-CA-independent manner (Additional file 1: Figure S2). To confirm this, similar experiments were performed using D64A mutant virus, which is defective in integrase, co-infected with Ad-I-SceI (Figure 2A). PCR amplification followed by sequence analysis consistently detected the presence of pAC in the $5^{\prime}$ ends of the integrated viral LTR (Figure 2B).

We then estimated the frequency of viral integration into the DSB sites in the total number of provirus DNA. Intriguingly, we observed that more than half of the integrated D64V lentiviruses were present in the I-PpoI site (approximately 53\%) when viral infection was conducted using HT1080 cells that had been cultured in $0.1 \%$ FBS (Figure 2C, Additional file 1: Figure S3A). In contrast, the DSB-specific integration of the viral DNA was reduced to approximately $18 \%$ in a similar experiment performed in the presence of $10 \%$ FBS. FACS analysis of HT1080 cells that had been pulse-labeled with BrdU revealed that the population of cycling cells decreased from $43 \%$ to $18 \%$ when cells were cultured in 


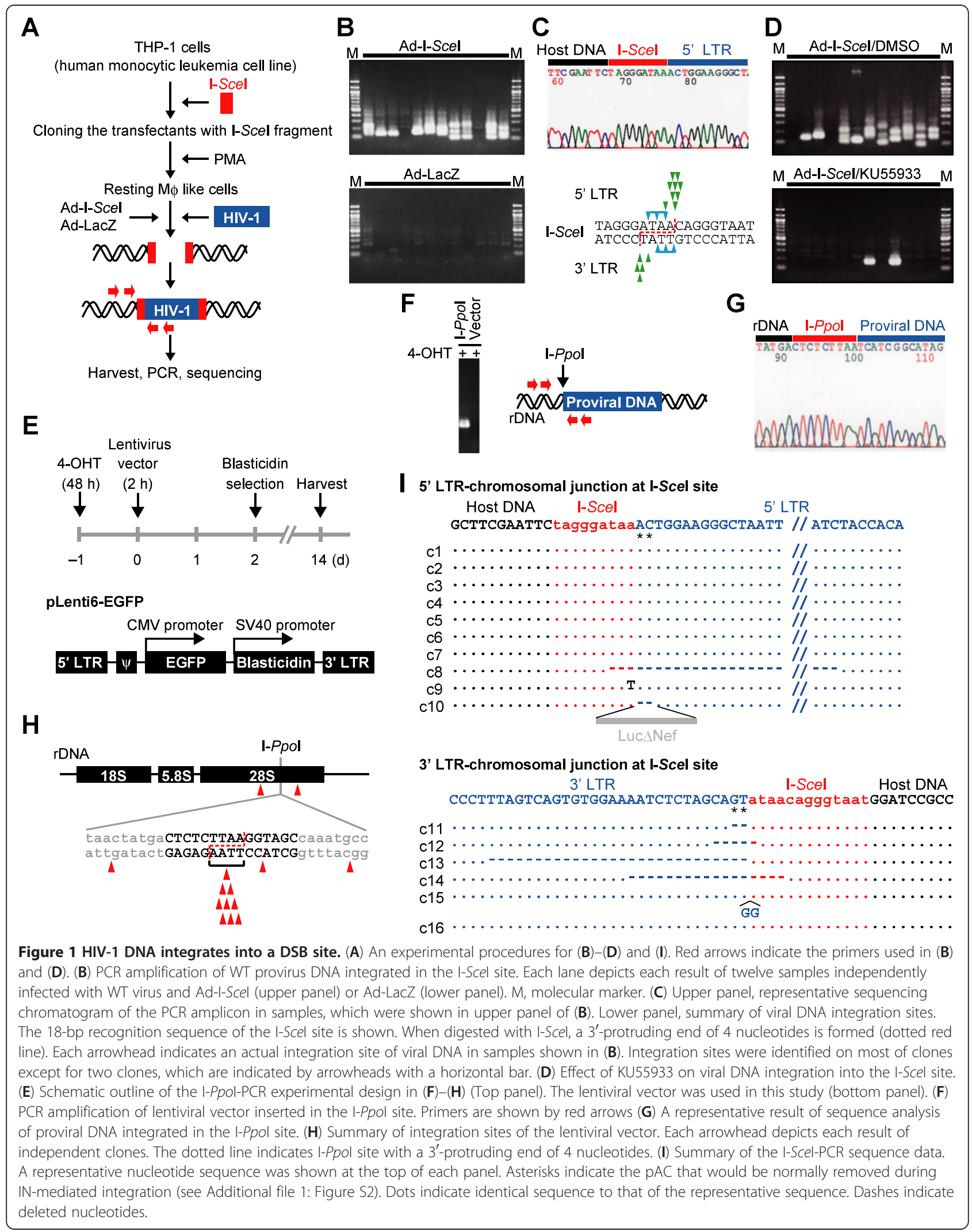




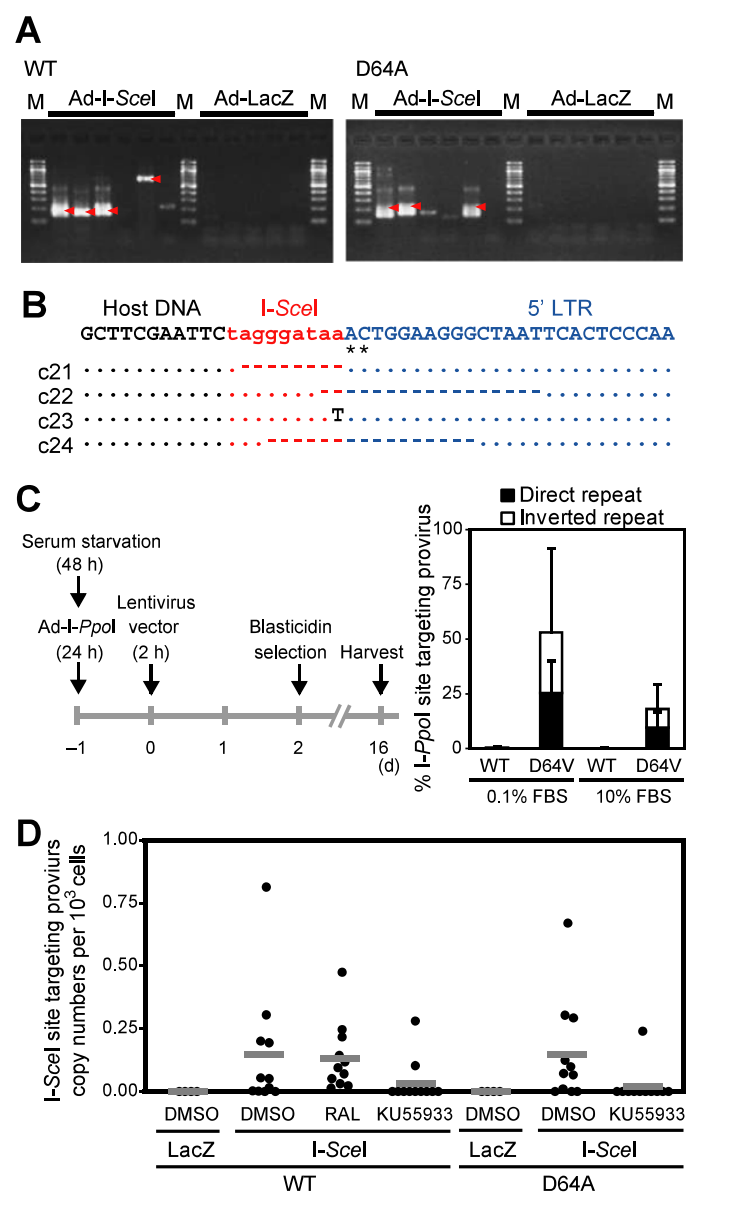

Figure 2 Frequent integration of the IN-CA defective virus into the DSB site. (A) PCR amplification of provirus DNA integrated into the I-Scel site after infection of WT virus (left) or NL-Luc-IN-D64A-E(-) $\mathrm{R}(-)$ virus (D64A virus) (right). PMA-treated THP-1/I-Scel cells were used. Each lane shows an independent result that was obtained from cells cultured in a single well of 6-multiwell. For each test group, six wells were independently infected with viruses. M, molecular marker. Arrowheads indicate amplicons of viral DNA integrated in the I-Scel site, which was further confirmed by sequence analysis. (B) Sequence data of D64A provirus DNA that was integrated in the I-Scel site. A representative result is shown at the top. Asterisks indicate the PAC. Dots indicate identical nucleotides to those of the representative sequence. Dashes indicate deleted nucleotides. (C) Experimental protocol for evaluating the frequency of viral integration into the DSB site. I-Ppol-qPCR and EGFP-qPCR analyses were done for quantification of I-Ppol sitespecific and total proviral DNA copy numbers, respectively. Representative data of two independent experiments was shown. Error bars, s.d. of triplicate assays. (D) Evaluation of I-Scel sitetargeting efficiency. PMA-treated THP-1/I-Scel cells were infected with WT or D64A virus for $2 \mathrm{~h}$, and cells were harvested 48 hpi for the I-Scel-qPCR analysis (see Methods section). To cleave the I-Scel site, cells were infected with the Ad-I-Scel at an MOI of 100 from $1 \mathrm{~h}$ post HIV-1 infection. Treatment with RAL and KU55933 was conducted from $-2 \mathrm{~h}$ to $48 \mathrm{hpi}$. Effects of RAL and KU55933 were evaluated on 11 samples that were prepared from three independent experiments. Each dot indicates copy numbers of provirus DNA that had integrated in the I-Scel site in $10^{3}$ cells, which were infected as a single test sample.
$10 \%$ and $0.1 \%$ FBS, respectively (Additional file 1, Figure S3B). The data indicated that the cellular conditions had a large influence on the rate of viral integration into DSB sites. Of note, no remarkable integration of WT virus into the DSB site was detected under any conditions of cell culture with different concentrations of FBS (Figure 2C). These data suggested that the IN-CA-defective virus was the main target of capture by the DSB sites.

To accurately determine the exact rate of DSB-specific integration of viral DNA, we developed a system for quantitative I-SceI-PCR (I-SceI-qPCR) analysis of the provirus DNA and investigated whether viral DNA integration into the I-SceI site was influenced by RAL (see experimental procedures in Methods section). As shown in Figure 2D, RAL did not attenuate the DSBspecific integration of WT viruses in PMA-treated THP-1 cells (a single dot indicates each result of 11 samples in three independent experimental groups). In contrast, KU55933 efficiently blocked the DSB-specific integration of WT and D64A viruses (Figure 2D). These data suggest that capture of viral DNA in the DSB sites was selectively induced in an IN-CA-independent manner, which was ATM-dependent.

\section{DNA damaging agents upregulate IN-CA-independent viral integration}

Next, we examined the effects of the DNA damaging agents etoposide and bleomycin on viral infection. As shown in Figure 3A, both compounds increased the infectivity of D64A virus in all cells examined, which included MDMs and various human cell lines. However, the positive effects of these compounds were not consistently observed in WT virus, although they ectopically enhanced the frequency of viral transduction (Figure 3B, Additional file 1, Figure S4), i.e., etoposide enhanced the infectivity of WT virus in serum-starved HT1080 cells and nocodazole-treated human primary fibroblasts (TIG-3) (Figure 3B, upper panels, Additional file 1, Figure S4) [24]. However, it had no positive effects when cells were cultured in the presence of $10 \%$ FBS (Figure 3B, upper panels, Additional file 1, Figure S4). In addition, bleomycin had no positive effects on the infectivity of WT virus under any culture conditions (Figure 3B, lower panels, Additional file 1, Figure S4). These data indicate that the effects of DNA damage on viral transduction are only observable when combined with the IN-CA-defective virus, or they are obscured by the infectivity of the WT virus.

\section{DSBs enhanced viral transduction at the integration step of viral infection}

We quantified the integrated DNA copy numbers to clarify the roles of DSBs in IN-CA-independent viral transduction in greater detail. We used serum-starved HT1080 cells to minimize the possible effects of DSBs generated 


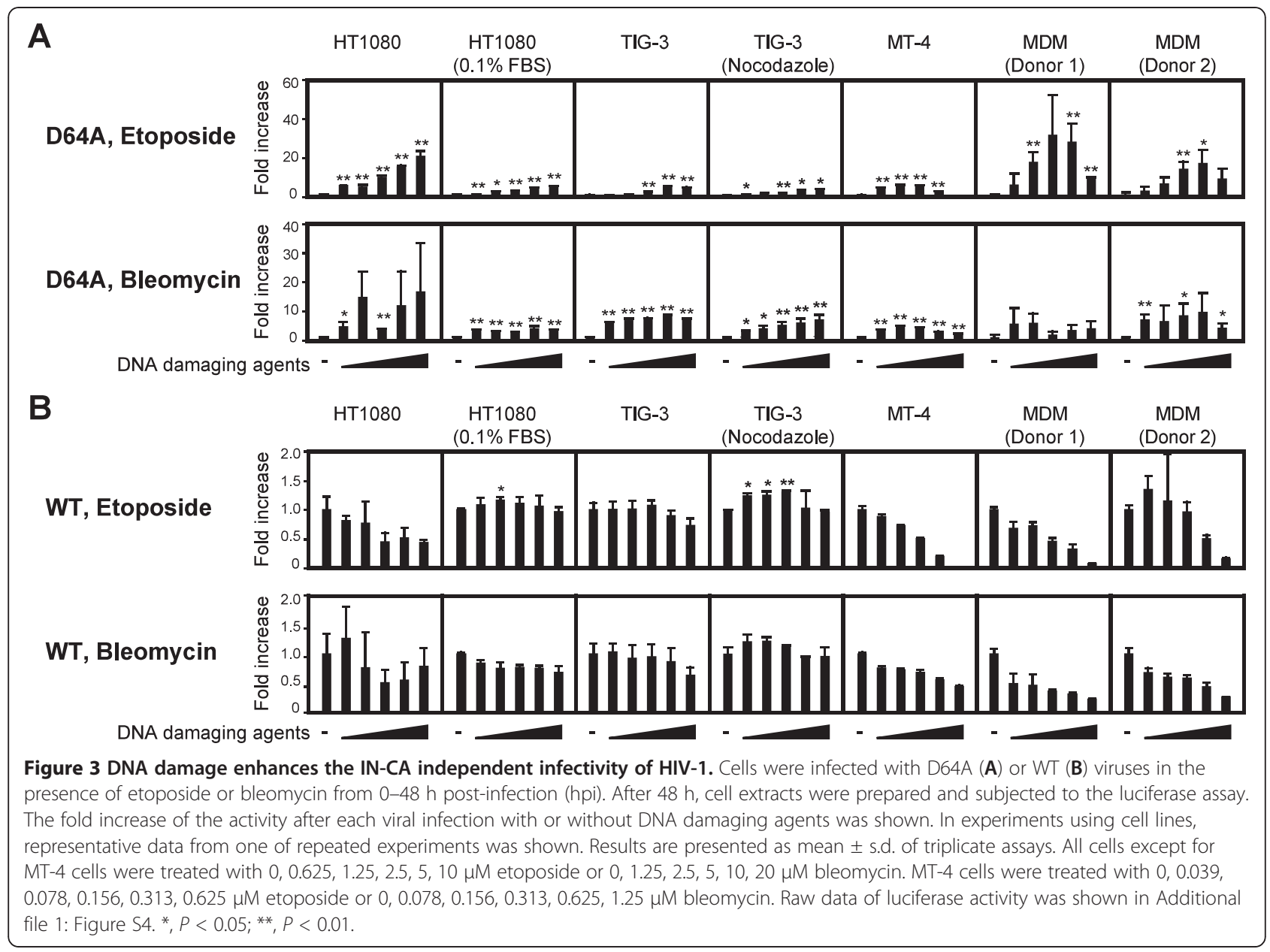

spontaneously during DNA replication. A quantitative PCR (qPCR)-based assay demonstrated that treatment with 1.25-20 $\mu \mathrm{M}$ etoposide or bleomycin significantly increased the number of integrated viral DNA copies (Figure 4A). We performed a colony formation assay to further demonstrate the effects of DNA damaging agents on viral transduction. As shown in Figure 4B, treatment with DNA damaging agents significantly increased the number of drug-resistant colonies, indicating that DSBs promoted the integration of D64A virus (Figure 4B). In contrast, these compounds had no obvious effects on the integration of WT virus (Figure $4 \mathrm{C}$ and D). Although it has been reported that DSBs augment viral replication during multiple steps [15], our observations suggested that they enhance the integration step of viral DNA, which is a pivotal step in viral transduction.

DSB-dependent viral integration induced minor structural alterations in provirus DNA but generated infectious progeny viruses

It has been proposed that a non-homologous endjoining (NHEJ) pathway is involved in the repair of the gaps formed during viral integration [25] and that the DSB-specific integration of provirus DNA is susceptible to structural alterations [26]. To evaluate this, we quantified the frequency of structural modifications with provirus DNA using linear amplification mediated-PCR (LAM-PCR), followed by nucleotide sequence analysis [27]. When cells were infected with the virus in the presence of RAL, insertions and deletions in the $5^{\prime}$-LTR region were detected in $70.6 \%$ and $35.3 \%$ of cells, respectively (Table 1 ). In contrast, only $5 \%$ of the integrants were positive for structural alterations when infected in the presence of dimethyl sulfoxide (DMSO, solvent control) (Table 1 and Additional file 1: Figure S5). The data implicated that viral integration in the presence of RAL is susceptible to disruption of provirus DNA structures, which abrogated the production of secondary viruses.

To clarify this possibility, we investigated the effects of RAL on single-round viral infection using several cell lines. As shown in Figure 5A, we found that the infectivity of the WT virus was significantly attenuated by RAL, i.e., viral infection was reduced to $0.2 \%$ and $3.8 \%$ when $10 \mu \mathrm{M}$ RAL was used to treat MAGIC5 cells and MT-4 

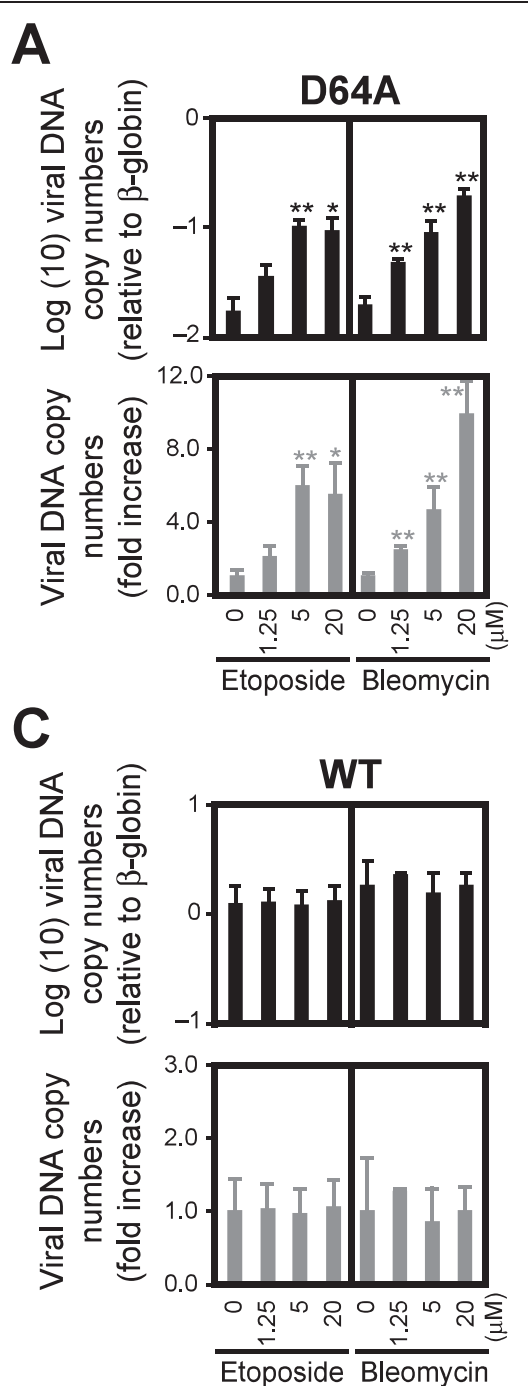

B

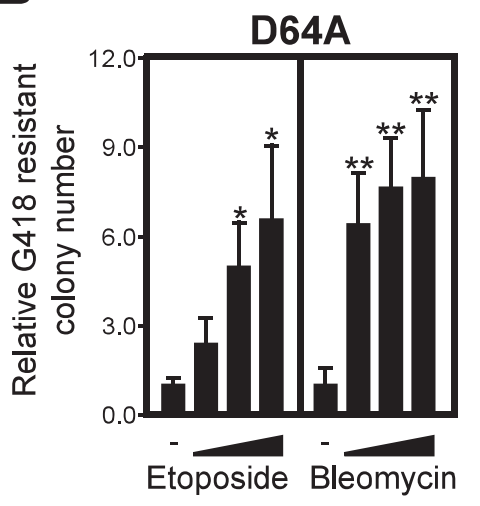

D

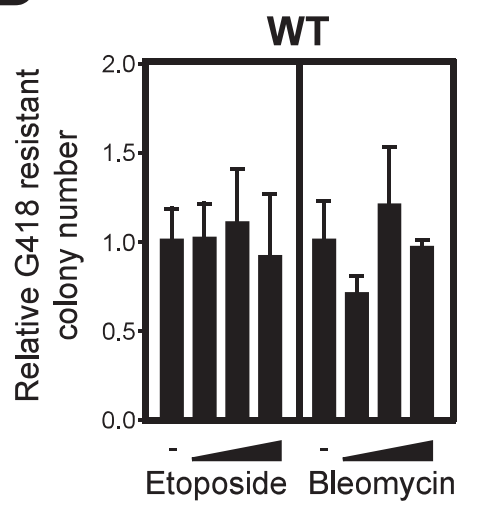

Figure 4 DNA damage enhances the integration rate of HIV-1. Serum-starved HT1080 cells were infected with D64A (A) or WT (C) viruses in the presence of etoposide or bleomycin from 0-24 hpi. After 48 h, genomic DNA was extracted and subjected to qPCR. Relative copy numbers of HIV-1 DNA to $\beta$-globin were estimated (top) and the fold increase of HIV-1 DNA copy number compared to control infection that was conducted without DNA damaging agents (bottom) were calculated. For colony formation assay, VSVG-pseudotyped D64A (NL-Neo-IN-D64A-E(-) $\mathrm{R}(-))(\mathbf{B})$ or WT (NL-Neo-E(-)R(-)) (D) viruses, which had the neomycin resistant gene (Neo ${ }^{\mathrm{R}}$, were used. HT1080 cells were treated with various doses of etoposide or bleomycin for $24 \mathrm{~h}$, which were added at the same time of viral infection. After selection with $600 \mu \mathrm{g} / \mathrm{mL}$ of G418, numbers of $\mathrm{NeO}^{\mathrm{R}}$ colonies were counted. Numbers of $\mathrm{Neo}^{\mathrm{R}}$ colonies were normalized by plating efficiency. Error bars, s.d. of triplicate assays. ${ }^{*} P<0.05 ;{ }^{* *} P<0.01$.

cells, respectively. However, these values were the same with D64A virus, which suggests that restricting IN-CA could not block viral infection completely. This suggestion was supported by tests using azidothymidine (AZT, an RT inhibitor), which further blocked the infectivity of D64A virus. Importantly, the same results were obtained using elvitegravir (EVG, another IN-strand transfer inhibitor) in PMA-treated THP-1 cells (Figure 5A).

These observations strongly suggest that the WT virus can replicate in the presence of RAL, although the potential for viral replication is low and at similar level to IN-CA-defective virus. To test this possibility, we infected
MT-4 cells with a replication-competent virus in the presence of RAL and examined the production of the progeny virus using MAGIC5 cells (HeLa/CD4, CCR5, LTR- $\beta$-gal) [28]. As shown in Figure 5B, we observed viral replication with the WT virus, although RAL was continuously added in the culture medium (one representative result from three independent experiments is shown with other experimental data in Additional file 1: Figure S6A). To exclude the possibility that the secondary virus possessed mutations that could overcome the inhibitory effects of RAL, we tested the viral RNA recovered from the culture supernatants. Analysis of the nucleotide sequences of 10 
Table 1 HIV-1 DNA integration sites and host-virus junction sequence

\begin{tabular}{|c|c|c|c|c|c|c|c|}
\hline Seq ID & Inhibitor & Chr & Locus & Strand & RefSeq gene & Insertion & Deletion \\
\hline 100902 & DMSO & 20 & 33371451 & plus & NCOA6 & - & - \\
\hline 100903 & DMSO & 17 & 35993714 & minus & DDX52 & - & - \\
\hline 100904 & DMSO & 3 & 156651874 & minus & LEKR1 & - & - \\
\hline 100906 & DMSO & 20 & 60900963 & minus & LAMA5 & - & - \\
\hline 100907 & DMSO & 3 & 19680267 & minus & DLG1 & - & - \\
\hline 100910 & DMSO & 4 & 150767744 & plus & - & - & - \\
\hline 100912 & DMSO & 9 & 131400460 & plus & WDR34 & - & - \\
\hline 100914 & DMSO & 1 & 156020423 & minus & UBQLN4 & $11 \mathrm{bp}$ (ACAGCAGTTAG) & $37 \mathrm{bp}$ \\
\hline 100916 & DMSO & 17 & 43551920 & minus & PLEKHM1 & - & - \\
\hline 100919 & DMSO & 20 & 2467413 & minus & ZNF343 & - & - \\
\hline 100921 & DMSO & 10 & 114725221 & minus & TCF7L2 & - & - \\
\hline 106501 & DMSO & 4 & 87017147 & plus & MAPK10 & - & - \\
\hline 106502 & DMSO & 2 & 98458616 & minus & TMEM131 & - & - \\
\hline 106505 & DMSO & 15 & 44399565 & minus & FRMD10 & - & - \\
\hline 106506 & DMSO & 2 & 197544261 & plus & CCDC150 & - & - \\
\hline 106510 & DMSO & 7 & 333212296 & minus & BBS9 & - & - \\
\hline 106513 & DMSO & 2 & 230499770 & plus & DNER & - & - \\
\hline 106520 & DMSO & 17 & 38682989 & plus & CR597260 & - & - \\
\hline 106521 & DMSO & 19 & 17213409 & minus & MY09B & - & - \\
\hline 106524 & DMSO & 6 & 33219360 & plus & VPS52 & - & - \\
\hline 100925 & RAL & 9 & 33033919 & plus & DNAJA1 & - & $9 \mathrm{bp}$ \\
\hline 100931 & RAL & 14 & 44024820 & minus & - & - & $20 \mathrm{bp}$ \\
\hline 100937 & RAL & 2 & 102387409 & plus & MAP4K4 & $9 \mathrm{bp}$ (GACACTTAG0 & - \\
\hline 100940 & RAL & 5 & 176735496 & plus & MXD3 & $2 \mathrm{bp}(\mathrm{AC})$ & - \\
\hline 100944 & RAL & 3 & 105267040 & plus & - & $21 \mathrm{bp}$ (AATAAAAAGGTACAAATAGAC) & - \\
\hline 106525 & RAL & 14 & 87606685 & minus & - & $6 \mathrm{bp}$ (TCATAA) & $3 \mathrm{bp}$ \\
\hline 106530 & RAL & 22 & 36006496 & plus & $\mathrm{MB}$ & $1 \mathrm{bp}(\mathrm{A})$ & $9 \mathrm{bp}$ \\
\hline 106534 & RAL & 7 & 130544996 & minus & CR618431 & 10 bp (TTGTAATTAC) & - \\
\hline 106537 & RAL & 1 & 63779999 & minus & BC040309 & 16 bp (AAAGAAAAGGGGGGAC) & - \\
\hline 106538 & RAL & 3 & 190624485 & minus & - & - & $4 \mathrm{bp}$ \\
\hline 106540 & RAL & 3 & 85084717 & minus & CADM2 & - & - \\
\hline 106542 & RAL & 18 & 40381428 & minus & RIT2 & $2 \mathrm{bp}(\mathrm{CA})$ & $1 \mathrm{bp}$ \\
\hline 106558 & RAL & 6 & 52427867 & minus & TRAM2 & - & - \\
\hline 106574 & RAL & 9 & 18460635 & plus & - & $9 \mathrm{bp}$ (ACACCTAAT) & - \\
\hline 106582 & RAL & 1 & 6482403 & minus & HES2 & $4 \mathrm{bp}(\mathrm{GGAC})$ & - \\
\hline 106588 & RAL & 11 & 28954901 & plus & - & $4 \mathrm{bp}(\mathrm{GGAC})$ & - \\
\hline 106596 & RAL & 7 & 92394729 & plus & CDK6 & $4 \mathrm{bp}(\mathrm{GGAC})$ & - \\
\hline
\end{tabular}

HIV-1 DNA integratio sites were determined by LAM-PCR. LAM-PCR sequence were aligned to the human genome reference (GRCh37/hg19, Feb. 2009, UCSC). Chr, chromosome.

progeny viruses revealed that all clones had no reported mutations related to RAL-resistant phenotypes (Table 2, Additional file 1, Table S1 and Figure S7) [29-32]. A similar experiment was performed using D64A virus. Again, we observed reproducible viral replication in the presence or absence of RAL (Figure 5C, Additional file 1:
Figure S6B). Analysis of the nucleotide sequence of the progeny virus RNA revealed that a single clone of the 10 viruses analyzed was positive for a reported mutation linked to a RAL-resistant phenotype (M154I in Table 2, Additional file 1, Table S1). However, the other nine clones were free of such mutations. In addition, no WT virus revertants 


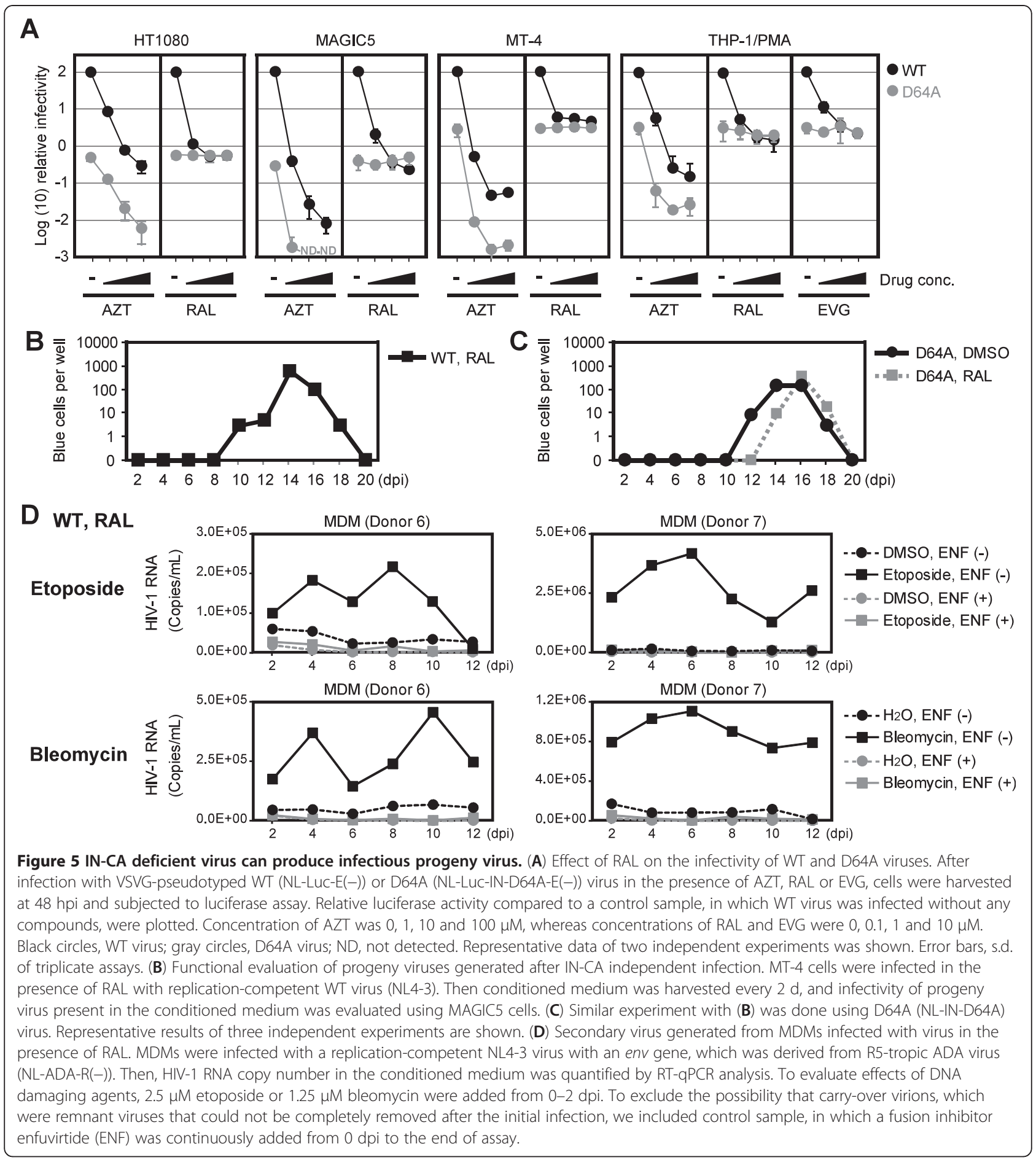

were detected. It is interesting to note that MT-4, a cell line infected with human $\mathrm{T}$ cell leukemia virus, expresses Tax, a viral protein. One possible explanation for the efficient IN-CA independent viral infection is due to DNA damage that is induced by the biological activity of Tax [33,34].

After establishing that RAL-resistant viral replication could be induced in MT-4 cells, we investigated whether the same mode of viral infection can occur in MDMs. We detected no apparent replication of infectious secondary virus in MDMs, which were infected in the presence of RAL. However, viral replication was detected when DNA damaging agents were treated at the same time as the viral infection (Figure 5D). Importantly, the addition of enfuvirtide (ENF), a fusion inhibitor, 
Table 2 IN mutations of NL-ADA or NL-IN-D64A-ADA viruses in Figure 5B and 5C

\begin{tabular}{|c|c|c|c|}
\hline Virus & $\begin{array}{r}\text { Clone } \\
\#\end{array}$ & RNA & Amino acid \\
\hline \multirow[t]{10}{*}{ WT/RAL } & $\# 1$ & - & - \\
\hline & \#5 & - & - \\
\hline & \#6 & - & - \\
\hline & \#7 & - & - \\
\hline & \#8 & - & - \\
\hline & \#9 & - & - \\
\hline & $\# 10$ & - & - \\
\hline & \#2 & $\mathrm{A} 144 \mathrm{G}$ & E48E (Silent) \\
\hline & \#3 & A87G & P29P (Silent) \\
\hline & \#4 & A731G & R244K \\
\hline \multirow{10}{*}{$\begin{array}{l}\text { D64A/ } \\
\text { DMSO }\end{array}$} & $\# 1$ & A191C & D64A \\
\hline & \#2 & A191C & D64A \\
\hline & \#3 & A191C & D64A \\
\hline & \#4 & A191C & D64A \\
\hline & \#7 & A191C & D64A \\
\hline & \#9 & A191C & D64A \\
\hline & \#5 & A191C, A772G & D64A, K258E \\
\hline & \#6 & A191C, U842A & D64A, V281E \\
\hline & \#8 & A38G, A191C, G462A & E13G, D64A, M154I \\
\hline & $\# 10$ & A191C, A279, A809G & $\begin{array}{r}\text { D64A, T93T (Silent), } \\
\text { D270G }\end{array}$ \\
\hline \multirow[t]{10}{*}{ D64A/RAL } & $\# 1$ & A191C & D64A \\
\hline & \#4 & A191C & D64A \\
\hline & \#8 & A191C & D64A \\
\hline & $\# 10$ & A191C & D64A \\
\hline & \#2 & A191C, G806C & D64A, R269T \\
\hline & \#3 & A191C, A718G & D64A, K240E \\
\hline & \#5 & A191C, G829U & D64A, G277C \\
\hline & \#6 & A191C, U598C & D54A, I200T \\
\hline & $\# 9$ & A191C, G462A & D64A, M154I \\
\hline & \#7 & $\begin{array}{r}\text { G7A, G39A, G103A, } \\
\text { A191C }\end{array}$ & $\begin{array}{r}\text { D3N, E13E (Silent), E35K, } \\
\text { D64A }\end{array}$ \\
\hline
\end{tabular}

Nucleotide sequence of progeny viral RNA was analyzed. In two of 20 clones examined, we identified M1541, which was reported as a mutation related to RAL-resistant phenotype [30].

completely abolished the detection of the viral RNA, which indicated that the detected virus was not a remnant of the initially infected virus and that it was a progeny virus. Similar results were obtained in independent experiments using MDMs prepared from a different donor. These data and the absence of reported mutations in these viral RNA showed that DSBs promoted productive viral transduction even in the presence of RAL.
Based on these experiments, we expected that DSB site may capture and incorporate virus DNA as a structurally intact form. To obtain direct evidence for this possibility, we analyzed the nucleotide sequences of the provirus DNA integrated in the DSB site. In these experiments, serum-starved HT1080 cells were co-infected with an Ad-I-PpoI and an IN-defective lentiviral vector (Lenti6-EGFP-D64V), which contained a blasticidin-resistant gene. After infection, the blasticidinresistant cells were selected and cloned, and the lentivirusinfected cell clones were screened using I-PpoI-qPCR. We isolated a total of 74 clones and obtained 10 (13.5\%), five (6.8\%), and five (6.8\%) clones, which contained proviral DNA at the I-PpoI site in direct, inverted, or both direct and inverted orientations, respectively (Figure 6A). Of these, five clones were EGFP-positive (Figure 6B) and the proviral DNA was integrated only into the I-PpoI site in one of these clones (Figure 6C, D, clone \#2413). This was further confirmed by fluorescent in situ hybridization (FISH) analysis, which detected provirus DNA in a single locus in the genome (Figure 6E). Sequence analysis of the provirus DNA of clone \#2413 finally identified an intact viral DNA structure with the flanking nucleotide sequence of the I-PpoI site (Figure 6F). The data indicated clearly that the structurally intact viral DNA could integrate into the DSB site.

\section{Vpr mimicked DSBs and enhanced the IN-CA-independent viral transduction into resting macrophages}

$V p r$, an accessory gene of HIV-1, encodes a 96-amino acid virion-associated nuclear protein with pleiotropic activities, including a cell cycle abnormality during the G2/M phase, enhanced promoter activity and apoptosis. It has also been proposed that $\mathrm{Vpr}$ is important for macrophage infection through the nuclear trafficking of a preintegration complex [35]. Previously, it has been reported that $\mathrm{Vpr}$ elicits cellular signals triggered by DNA damage [36-40], which suggests that Vpr promotes IN-CA-independent viral transduction. To test this hypothesis, we checked whether infection with $\mathrm{R}+$ virus induced the DNA damage response in MDMs (Figure 7A). In agreement with our previous observations, infection with $\mathrm{R}+$ virus evoked the cellular response triggered by DNA damage $[36,37,41,42]$. We investigated the infectivity of $\mathrm{R}+$ virus and observed that $\mathrm{Vpr}$ enhanced viral transduction in the presence of RAL, which was blocked by AZT (Figure 7B). Similar to the effect of DSBs, $\mathrm{Vpr}$ enhanced the viral infectivity during the integration step (Figure 7C). Moreover, $\mathrm{Vpr}$ enhanced the infection of MDMs by D64A virus (Figure 7D and Additional file 1: Figure S8).

To further elucidate the effects of $\mathrm{Vpr}$ on the infection of MDMs, we compared the efficiency of viral transduction 


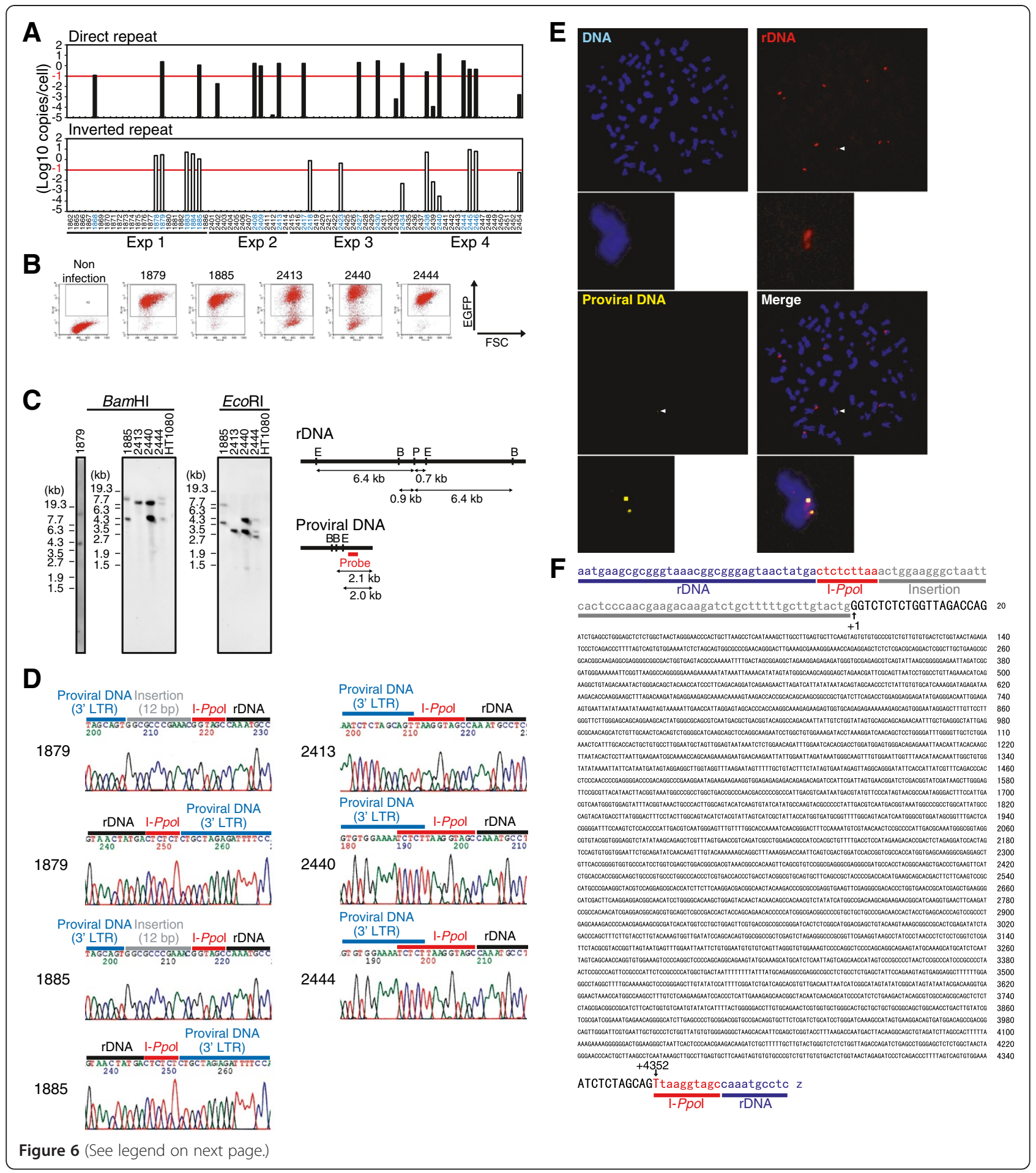


(See figure on previous page.)

Figure 6 Detection of intact provirus DNA in the DSB site. (A) I-Ppol-qPCR screening of cell clones containing provirus DNA in I-Ppol site. HT1080 cells were infected with Ad-I-Ppol at an MOI of 30 in the medium with $0.1 \%$ FBS. After 24 h, cells were further infected with lentiviruses (VSVG-pseudotyped Lenti6-EGFP-D64V) also under serum-starved conditions. Two h later, medium was changed with fresh one with 0.1\% FBS. On the next day, medium was replaced with a complete medium with 10\% FBS. Blasticidin-resistant colonies were isolated and I-Ppol site targeting provirus was detected by I-Ppol-qPCR. The threshold of detecting provirus integrated as direct or inverted repeat orientation was -1 log(10) copies/cell (indicated in red horizontal lines). (B) EGFP expression analysis. Cells containing the proviral DNA in I-Ppol site in (A) were further analyzed for the expression of EGFP by flow cytometer. (C) The estimation of proviral DNA copy number. Copy numbers of provirus DNA in EGFP-positive clones, shown in (B), were analyzed by Southern blot by using a part of DNA fragment of the lentiviral vector as a probe. Genomic DNA extracted from each clone was digested with BamHI or EcoRI prior to electrophoresis. Restriction maps are shown (right panel). B, BamHI; $\mathrm{E}$ EcoRl; P, I-Ppol. Of note, clone \#2413 possessed a single copy of provirus DNA. (D) Sequence analysis of lentiviral vector integrated in the I-Ppol site. EGFP-positive clones shown in (B) were subjected to sequence analysis. I-Ppol-PCR amplicons were directly used as a template for sequence analysis. (E) FISH analysis of the \#2413 clone. (F) Nucleotide sequence of intact proviral DNA present in the DSB site. The proviral DNA of \#2413 clone was sequenced and whole nucleotide sequence data was shown. In \#2413 clone, no structural alternations of provirus DNA were detected.

into MDMs, peripheral blood mononuclear cells (PBMCs), and human cell lines by calculating the fold-increase in the luciferase activity, which reflected the infectivity of each virus (Figure 7E, Additional file 1, Figure S9). As summarized in Figure 7F, the positive effects of $\mathrm{Vpr}$ were the most striking when MDMs were infected with D64A virus (D64A/R+ virus). The infectivity of $\mathrm{D} 64 \mathrm{~A} / \mathrm{R}+$ virus in MDMs was 37.0-265.1-fold higher than that of D64A/Rvirus. In contrast, these positive effects were not detected with the $\mathrm{WT} / \mathrm{R}+$ virus. Moreover, the positive effects of Vpr were less conspicuous in PBMCs, consistent with previous observations that $\mathrm{Vpr}$ functions as a positive factor during viral transduction into MDMs [43]. Combined with previous reports that Vpr activates ATM [36,37] and ATR [38], our observations suggest that the enhanced infectivity of D64A/R+ virus in MDMs is attributable to Vpr-induced DSBs [36,37].

\section{Discussion}

Since it was first postulated that the cellular proteins responsible for DNA damage repair are positively involved in HIV-1 infection [9], roles of DSBs and DNA damage repair enzymes in viral infection have remained controversial [10-14,16-19,44]. However, several lines of evidence have suggested that DSBs have at least two roles in viral infectivity, i.e., direct upregulation of the rate of viral DNA integration into the host genome and the activation of DNA damage repair enzymes, which contribute to multiple steps in HIV-1 infection including repair of the gaps formed during the integration of viral DNA into the host genome [15]. Here we focused on the first possibility and provided experimental data, which showed that DNA damage increased the frequency of viral integration into the host genome.

In particular, we found that DSBs promoted the transduction of D64A virus, which was defective with respect to the catalytic activity of integrase (IN-CA). Moreover, DSBs upregulated the infectivity of WT virus by overcoming the inhibitory effects of RAL, an IN-CA inhibitor. Furthermore, infectious secondary viruses were generated from the provirus DNA formed through INCA-independent viral transduction. Our observations were highly consistent with previous reports that the IN-CA-defective virus can integrate into the host genome [45-47]. Ebina et al. reported that the integration rate of the IN-CA-defective virus was enhanced by DNA damaging agents such as $\mathrm{x}$-ray irradiation or hydrogen peroxide [48], whereas we showed that DSBs upregulated IN-CA-independent viral integration and promoted the production of secondary viruses, which were competent for subsequent viral infection. Importantly, analysis of the nucleotide sequences of the viral RNA from the secondary viruses showed that there were no revertants to WT virus. Most of the viruses analyzed also had no reported mutations linked to RAL-resistant phenotypes [29-32]. Taken together with observation that RAL could reduce the infectivity of WT virus at a similar level to D64A virus, our data also suggest that currently available IN inhibitors cannot completely block productive viral infection, which is possibly enhanced by DSBs.

The mechanism of DSB-induced upregulation of viral transduction remains elusive but our data suggest that DSB sites provide a platform where viral DNA integrates in an IN-CA-independent manner. When cells were co-infected with HIV-1 virus and an adenovirus that expressed rarecutting endonucleases such as I-SceI or I-PpoI, we reproducibly observed that the viral DNA was integrated into the corresponding DSB sites. However, interestingly, DSB-site specific viral integration was influenced by viral and cellular factors. First, we observed that targeting of viral DNA to the DSB site was observed mainly during INCA-independent viral transduction, although its frequency was low compared with WT virus. Second, it was influenced by the cellular conditions of the target cells, i.e., the frequency of IN-CA-independent viral transduction into DSB sites decreased from approximately $53 \%$ to $18 \%$ when the concentration of FBS was changed from $0.1 \%$ to $10 \%$ (Figure $2 \mathrm{C}$ ). These results and the FACS analysis suggest that this difference may be because the spontaneous DSBs generated during DNA replication also captured viral 


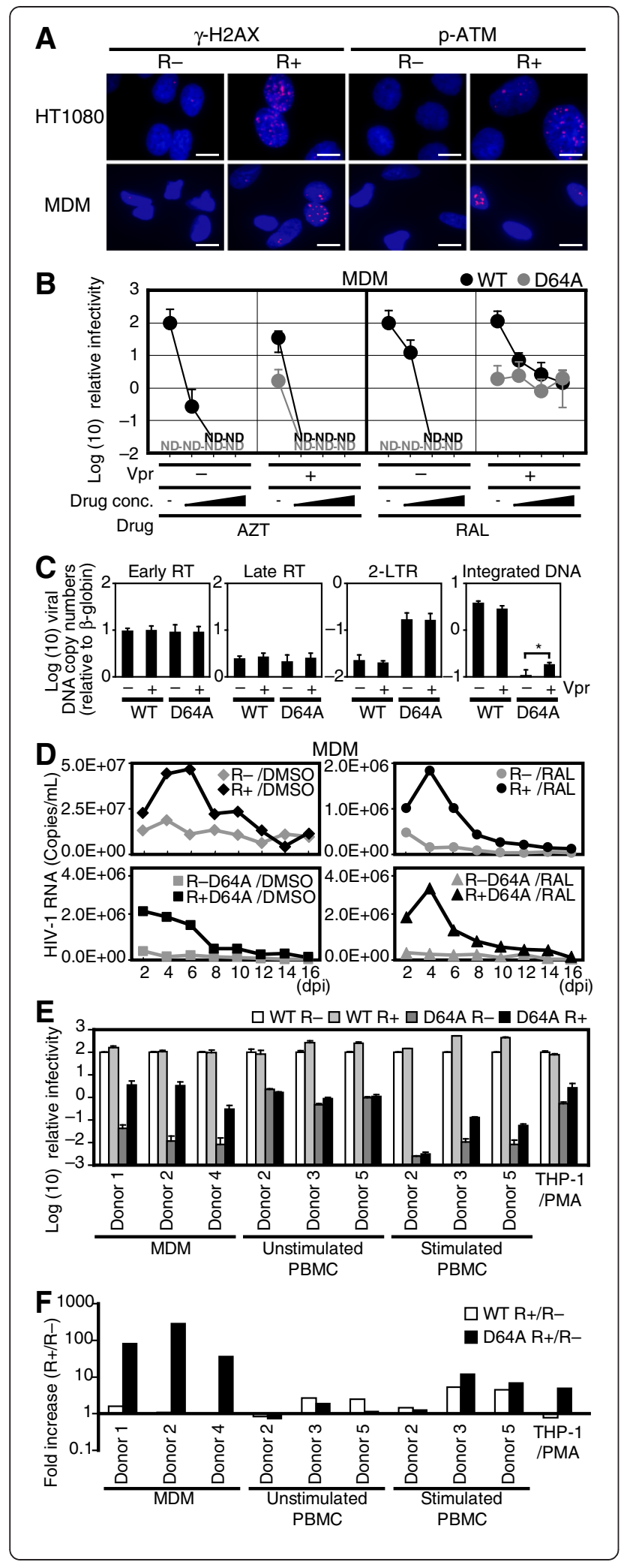

Figure 7 Vpr mimics DNA damaging agents, and enhances the IN-CA independent macrophage infection. (A) Vpr induces DNA damage cellular signals in MDMs. HT1080 cells or MDMs were infected with VSVG-pseudotyped R- virus (NL-Luc-E(-)R(-)) or R+ virus (NL-Luc-E(-)), and then analyzed immunochemically. Bars $=10 \mu \mathrm{m}$. (B) Effect of RAL on the infectivity of WT and D64A viruses. MDMs were infected with WT or D64A viruses in the presence of AZT or RAL. The cells were harvested at $48 \mathrm{hpi}$ and subjected to luciferase assay. Relative luciferase activity values to WT R- infectivity are shown. Black circles, WT; gray circles, D64A; ND, not detected. Error bars, s.d. of triplicate assays. (C) Effects of Vpr on the integration of viral DNA into the host genome. Serum-starved HT1080 cells were infected with VSVG-pseudotyped IN WT or D64A mutant virus with or without Vpr. After 48 h, infected cells were subjected to $\mathrm{qPCR}$ analysis. Error bars, s.d. of triplicate assays. ${ }^{*} P<0.05$. (D) HIV-1 replicates in MDMs in the presence of RAL.

Replication-competent NL4-3 with an intact env gene derived from R5-tropic ADA viruses (NL-ADA, NL-ADA-R(-), NL-ADA-IN-D64A, and NLADA-IN-D64A-R(-)) were infected. Then, copy numbers of HIV-1 RNA in the conditioned medium was quantified by RT-qPCR. E and F) Positive effects of Vpr on infection of D64A virus into MDMs. Primary cells and cell lines were infected with IN WT or D64A mutant virus with or without Vpr. Cells were harvested at $48 \mathrm{hpi}$ and subjected to luciferase assay. (E) Relative luciferase activity values to WT R-infectivity are shown. White bars, WT/R-; light gray bars, WT/R+; dark gray bars, D64A/R-; black bars, D64A/R+. Error bars, s.d. of triplicate assays. (F) Fold increase of $\mathrm{R}+$ virus infectivity to R- virus. White bars, WT; black bars, D64A.

DNA, which resulted in a decrease in the relative rate of viral integration into artificially induced DSBs.

Interestingly, the DSB-specific integration of DNA fragments has been reported for hepatitis B virus DNA, an adeno-associated viral vector (AAV) [49,50], and Ty1 [51], a DNA retrotransposon of Saccharomyces cerevisiae. These observations suggest that the DSB site-specific integration of exogenous DNA fragments is not lentivirus-specific, which also indicates that DSB site-specific integration is dependent on the cellular response to DNA damage. We observed that KU55933, a specific ATM inhibitor, consistently blocked DSB-specific viral integration (Figures $1 \mathrm{D}$ and 2D). Interestingly, $\mathrm{x}$-ray irradiation triggers the retrotransposition of long interspersed element 1 in human cells, which is also dependent on ATM [52], implying that a conserved cellular response to DNA damage is functionally involved in the capture of viral DNA in the DSB site.

We detected minor nucleotide deletions of approximately $<9$ bp in five of six clones of the provirus DNA, which were derived from cells infected with virus in the presence of RAL (Table 1). Such structural alternations would be due to the NHEJ repair system that is involved in viral integration in the presence of RAL. Because it has been reported that provirus DNA with 10-bp deletions from nucleotides +3 to +12 in the $5^{\prime}$-LTR remained functional [53], such provirus DNA is likely to be replication competent, although minor modifications in the $5^{\prime}$-LTR may be related to reduced expression of viral mRNA, as reported by Ebina et al. [48]. 
Several researchers have proposed that viral mRNA is expressed from non-integrated viral DNA of the IN-CA-defective virus [54,55], whereas $\mathrm{Vpr}$ was shown to promote Nef mRNA expression from such an extrachromosomal viral DNA [56]. However, our study clearly indicated that Vpr upregulates integration of IN-CA-defective virus into the host genome. The positive effects of Vpr on viral transduction were more prominent in MDMs than in PBMCs, well consistent with reports that $\mathrm{Vpr}$ functions as a positive factor during viral transduction into MDMs. Combined with observations that Vpr activates ATM [36,37] and ATR [38] and that macrophages are resistant to DSBs compared with monocytes [20], our data suggest that the enhancement of IN-CA-independent viral transduction into MDMs may be a pivotal role of Vpr in HIV-1 infection.

In summary, our observations may have major importance in the debate on the involvement of cellular factors in viral integration. It has been postulated that DNA damage sensor molecules are involved in the efficient integration of viral DNA. It has also been claimed that DNA damage sensor proteins have no involvement in DNA damage-dependent viral integration. Here we showed that DSBs are particularly important for IN-CA-independent viral transduction and that the effects of DSBs should be analyzed in carefully designed experimental conditions or else their effects are obscured. Collectively, our data suggest that complete prevention of viral integration will require the development of novel compounds that can protect cells from IN$\mathrm{CA}$-independent viral integration.

\section{Conclusion}

The ATM-dependent mode of the DSB-specific viral DNA integration and Vpr-induced DSBs may be novel targets for anti-HIV compounds that inhibit viral transduction into MDMs, which are a persistent focus of HIV-1 infection.

\section{Methods}

\section{Plasmid constructs}

The vesicular stomatitis virus glycoprotein (VSVG) expression vector $\mathrm{pHIT/G}$ [57], the HIV-1 proviral construct pNL4-3 [58], pNL-ADA [59], and the HIV-1 proviral indicator constructs pNL-Luc-E(-) and pNL-Luc-E(-)R(-) [37] have been described previously. To introduce D64A mutation into IN (adenine of nucleotide 4420 to cytosine) to create pNL-IN-D64A, site-directed mutagenesis (QuikChange; Stratagene) was performed using pNL4-3 as a template. To create pNL-ADA-IN-D64A and pNL-Luc-IN-D64A-E(-) that contained D64A mutants, the SpeI-PflMI fragment (nucleotides 1507-5297) of pNL-IN-D64A was replaced with those of $\mathrm{pNL}-\mathrm{ADA}$ and $\mathrm{pNL}-\mathrm{Luc}-\mathrm{E}(-)$, respectively. To create the Vpr-deficient construct pNL-ADA-R(-),
pNL-ADA-IN-D64A-R(-), and pNL-Luc-IN-D64A-E(-) $\mathrm{R}(-)$, the PflMI-SalI fragment (nucleotides 5297-5785) of pNL-Luc-E(-)R(-) was replaced with those of pNLADA, pNL-ADA-IN-D64A, and pNL-Luc-IN-D64A$\mathrm{E}(-)$, respectively.

The neomycin-resistant marker expressing vector $\mathrm{pNL}$ Neo-E(-)R(-) was created by inserting a PCR-amplified neomycin-resistant gene into the NotI-XhoI site of pNLLuc-E(-)R(-). To create a neomycin-resistant marker expressing D64A, the mutant pNL-Neo-IN-D64A-E(-) $\mathrm{R}(-)$ was created by the SpeI-PflMI fragment (nucleotides 1507-5297) of pNL-IN-D64A and replaced with that of pNL-Neo-E(-)R(-). To create pIRES2-EGFP-I-SceI, a pIRES2-EGFP (Clontech)-based plasmid with an I-SceI recognition site, a synthetic double-stranded oligonucleotide (I-SceI-sense and I-SceI-antisense oligonucleotides; see Additional file 1: Table S2) was inserted into the EcoRI and $\mathrm{BamHI}$ sites of pIRES2-EGFP.

To make the adenoviral vector Ad-I-PpoI, I-PpoI cDNA was amplified from pBabe-HA-ER-I-PpoI using the Adeno-PpoI-DraI-F and Adeno-PpoI-DraI-R primers (Additional file 1: Table S2) and cloned into the SwaI site of the pAxCALNLwtit2 cosmid vector (NIPPON GENE). To generate the EGFP-expressing lentiviral vector (pLenti6-EGFP), EGFP cDNA from pENTR1a-EGFP was cloned into pLenti6/V5-DEST (Invitrogen) using LR Clonase (Invitrogen). The IN D64V mutation of the gag/ pol-expressing plasmid pLP1 (Invitrogen; pLP1-IN-D64V) was introduced using pLP1 as a template with site-directed mutagenesis (QuikChange; Stratagene).

\section{Cell culture}

THP-1, HT1080, HEK293, and HEK293T cell lines were obtained from the RIKEN Cell Bank. TIG-3 (primary human fibroblast cells) and MT-4 cells were obtained from the Health Science Research Resources Bank (Osaka, Japan). HT1080, HEK293, HEK293T, MAGIC5, and TIG-3 cells were maintained in Dulbecco's modified Eagle's medium (DMEM) supplemented with 10\% fetal bovine serum (FBS). MT-4 cell was maintained in RPMI 1640 supplemented with $10 \%$ FBS. To obtain macrophage-like cells, THP-1 cells, maintained in Iscove's modified Dulbecco's medium supplemented with 10\% FBS, were treated for $2 \mathrm{~d}$ with $5.0 \times 10^{-8} \mathrm{M}$ PMA. As described previously [60], PMA-treated THP-1 cells were positive for Mac-1, a specific marker of macrophages. Peripheral blood was derived from healthy donors who worked within the institute and gave informed consent. Experimental procedures were approved by the internal review board. PBMCs and MDMs were prepared and cultured as previously described [61]. MDMs were prepared from healthy volunteers who gave informed consents. The experimental protocol was approved by the internal review board. 


\section{HIV-1 and lentiviral vector preparation}

The preparation and titration of replication-competent and VSVG-pseudotyped viruses are described elsewhere $[36,37,62,63]$. The lentiviral vectors were prepared using pLenti6-EGFP and the ViraPower Lentiviral Packaging Mix (Invitrogen) according to the manufacturer's protocol. Viral supernatants were centrifuged at $120 \times g$ for $5 \mathrm{~min}$, filtered through a $0.2-\mu \mathrm{m}$ filter, and stored at $-80^{\circ} \mathrm{C}$. To exchange the medium for DMEM supplemented with $0.1 \%$ FBS, the viruses were ultracentrifuged at $86,000 \times g$ for $1 \mathrm{~h}$.

\section{Quantitative PCR of provirus DNA}

For the quantification of early RT, late RT, 2-LTR circle, and integrated DNA, qPCR was performed as described elsewhere [64,65]. Briefly, cells were harvested at 48 hpi, and genomic DNA was prepared by QuickGene (FujiFilm). For the quantification of early RT, late RT, and 2-LTR circle products, the primers and probe sets M667/ AA55/R-U5, M667/M661/R-U5, and MH535/2-LTR-AS/ NL4-3-U3 were used, respectively. TaqMan Universal PCR Master Mix with UNG (Applied Biosystems) and ABI7000 (Applied Biosystems) were used according to the manufacturer's instructions. For Alu-PCR (quantification of integrated DNA), the primer and probe sets first-Alu-F/ first-Alu-R/first-gag-R and second-tag-R/2-LTR-S/probe-2 were used for the first and second rounds of qPCR, respectively. The amplification conditions for the first round of PCR, using AmpliTaq Gold 360 Master Mix (Applied Biosystems), were as follows: $95^{\circ} \mathrm{C}$ for $10 \mathrm{~min}$, followed by 12 cycles at $95^{\circ} \mathrm{C}$ for $15 \mathrm{~s}, 60^{\circ} \mathrm{C}$ for $30 \mathrm{~s}$, and $72^{\circ} \mathrm{C}$ for 10 min. The second round of $\mathrm{qPCR}$ was conducted using TaqMan Universal PCR Master Mix according to the manufacturer's instructions. To generate a standard curve for Alu-PCR, HEK293T cells (approximately one million cells) were infected with VSVG-pseudotyped NL-Luc-E(-) $\mathrm{R}(-)$ virus (200 ng p24), then harvested at $30 \mathrm{~d}$ postinfection (dpi), and genomic DNA was prepared. For the quantification of $\beta$-globin DNA copy numbers, the primer set globin-F/globin-R was used with SYBR Premix ExTaq (TaKaRa). Sequence information for primers and probes is listed in Additional file 1: Table S2.

\section{Cleavage of I-Scel and I-Ppol sites}

Ad-I-SceI and Ad-LacZ were prepared as described previously [36]. PMA-treated THP-1 cells were infected with Ad-I-SceI or Ad-LacZ at $1 \mathrm{~h}$ post-HIV-1 infection for $1 \mathrm{~h}$ at a multiplicity of infection (MOI) of 100 . In Figure $1 \mathrm{E}-1 \mathrm{H}$, HT1080 cells were transfected with plasmid DNA that encoded a chmeric protein of estrogen receptor-I-PpoI (ER-I-PpoI), and then 4-hydroxytamoxifen (4-OHT) was added to activate the endonuclease and induce DSB. The pAxCALNLwtit2 cosmid vector harboring I-PpoI cDNA was digested with Bsp T104I and transduced into HEK293 cells to produce Ad-I-PpoI. The adenoviral vector encoding Cre recombinase, AxCANCre (TaKaRa), was coinfected with Ad-I-PpoI at an MOI of 30 to remove the floxed stuffer between the CAG promoter and I-PpoI cDNA.

\section{Quantification of the I-Scel site specific viral integration}

PMA-treated THP-1 cells were co-infected with WT virus and Ad-I-SceI or Ad-LacZ, and then extracted genomic DNA was subjected to I-SceI-qPCR analysis. I-SceI site targeting integration rate of HIV-1 DNA was estimated by PCR amplification using primer sets pIRES2eGFP+ 543F/pNL4-3+9207R and pIRES2eGFP+574F/pNL4-3+ $98 R+9173 R$ for the first and second rounds of qPCR, respectively. The amplification conditions for the first round of PCR, using ExTaq polymerase (TaKaRa), were as follows: 30 cycles of $98^{\circ} \mathrm{C}$ for $10 \mathrm{~s}, 60^{\circ} \mathrm{C}$ for $30 \mathrm{~s}$, and $72^{\circ} \mathrm{C}$ for $30 \mathrm{~s}$. The second round of qPCR was conducted using SYBR Premix ExTaq polymerase (TaKaRa) according to the manufacturer's instructions. For the second round PCR template, $1 / 25$ the volume of the first PCR amplicon was used. To prepare a standard sample for the I-SceI-qPCR, the 5'-LTR DNA fragment of HIV-1 was amplified using the pNL4-3+9074F-Sce-RI and pNL4-3+9423R-BamHI and cloned into the EcoRI and BamHI sites of pIRES2EGFP (pIRES2-EGFP-5'-LTR). Then, HT1080 cells were transfected with pIRES2-EGFP-5'-LTR and HT1080/ pIRES2-EGFP-5'-LTR cell was obtained. By Southern blot and sequence analyses we confirmed that two copies of the DNA fragment of pIRES2-EGFP-5'-LTR vector were present in HT1080/pIRES2-EGFP-5'-LTR diploid cells. Sequence information for primers and probes is listed in Additional file 1: Table S2.

\section{Quantification of the I-Ppol site specific viral integration}

Serum starved HT1080 cells were co-infected with Ad-I-PpoI and lentiviruses, which were generated by pLenti6-EGFP or pLP1-IN-D64V. To estimate I-PpoI site targeting or total integration of the lentiviral vector, I-PpoIqPCR or EGFP-qPCR was conducted using the TaqMan Universal PCR Master Mix (Applied Biosystems). For IPpoI-qPCR in the direct or inverted repeat orientation, the primer sets rDNA+11725R/pLenti6+5237F or rDNA+ $11645 \mathrm{~F} / \mathrm{pLenti6}+5237 \mathrm{~F}$ were used, respectively; pLenti6LTR was used as the TaqMan probe. For EGFP-qPCR, the primers EGFP-F/EGFP-R and TaqMan EGFP-probe were used. As a standard sample for estimating copy numbers of viral DNA integrated in the I-PpoI site, genomic DNA of HT1080/Lenti6-EGFP-std cells were was used. We have confirmed by Southern blot and sequence analyses that HT1080/Lenti6-EGFP-std cells harbored two copies of Lenti6-EGFP proviral DNA in both orientations in the IPpoI site. On the other hand, as a standard sample for total provirus DNA, genomic DNA of HT1080/pIRES2-EGFP5'-LTR cells, which possessed two copies of EGFP, were 
used. Sequence information for primers and probes is listed in Additional file 1: Table S2.

\section{PCR and sequence analysis}

To amplify the host DNA/5'-LTR junction at the I-SceI site, the primer sets pIRES2eGFP+543F/pNL4-3+9207R and pIRES2eGFP+574F/pNL4-3+98R+9173R were used for the first and second rounds of PCR, respectively. To amplify the host DNA/3'-LTR junction at the I-SceI site, the primer sets pIRES2eGFP+1910R/L-M667 and pIRES2eGFP+887R/ LambdaT were used for the first and second rounds of PCR, respectively. The amplification conditions for the host DNA/5'-LTR and host DNA/3'-LTR were as follows: 40 cycles for the first round of PCR or 30 cycles for the second round of PCR at $98^{\circ} \mathrm{C}$ for $10 \mathrm{~s}, 60^{\circ} \mathrm{C}$ for $30 \mathrm{~s}$, and $72^{\circ} \mathrm{C}$ for $30 \mathrm{~s}$ and 35 cycles at $98^{\circ} \mathrm{C}$ for $10 \mathrm{~s}, 60^{\circ} \mathrm{C}$ for $30 \mathrm{~s}$, and $72^{\circ} \mathrm{C}$ for $60 \mathrm{~s}$ for the first round of PCR and $30 \mathrm{~s}$ for the second round of PCR, respectively. ExTaq polymerase (TaKaRa) was used for the PCR. PCR amplicons were used directly or cloned into pCR2.1-TOPO (Invitrogen) as a template for sequence analysis. To amplify the $\mathrm{rDNA} /$ lentiviral vector at the I-PpoI site in the direct repeat orientation, the primer sets rDNA+11784R/pLenti6+5208F and rDNA+11747R/ pLenti6+5232F were used for the first and second rounds of PCR, respectively. To amplify the rDNA/lentiviral vector at the I-PpoI site in the inverted repeat orientation, the primer sets $\mathrm{rDNA}+11589 \mathrm{~F} / \mathrm{pLenti6}+5208 \mathrm{~F}$ and $\mathrm{rDNA}+$ $11612 \mathrm{~F} / \mathrm{pLenti6}+5232 \mathrm{~F}$ were used for the first and second rounds of PCR, respectively. The amplification conditions for the $\mathrm{rDNA} /$ lentiviral vector at the I-PpoI site were as follows: 40 cycles for the first and second rounds of PCR at $98^{\circ} \mathrm{C}$ for $10 \mathrm{~s}, 60^{\circ} \mathrm{C}$ for $30 \mathrm{~s}$, and $72^{\circ} \mathrm{C}$ for $30 \mathrm{~s}$. ExTaq polymerase $(\mathrm{TaKaRa})$ was used for PCR. PCR amplicons were used directly or cloned into pCR2.1-TOPO (Invitrogen) as a template for sequence analysis. To analyze the IN mutations of NL-ADA and NL-IN-D64A-ADA viruses in Figure 5B and 5C, viral RNAs were isolated from conditioned medium (14 dpi; WT/RAL and D64A/DMSO, $16 \mathrm{dpi}$; D64A/RAL) and amplified by primer set pNL+ 4207F/pNL+5120R and Titan One-Tube RT-PCR Kit (Roche diagnostics). The amplicons were cloned into pCR2.1-TOPO and sequenced. The primers are listed in Additional file 1: Table S2.

\section{LAM-PCR}

To estimate the rate of insertion and/or deletion, the LAM-PCR method was performed as described previously [27,66]. Briefly, $1.0 \times 10^{6} \mathrm{HT} 1080$ cells were infected with VSVG-pseudotyped NL-Neo-E(-)R(-) virus (200 ng p24) in the presence of RAL or DMSO, and G418-resistant cells were harvested at $28 \mathrm{dpi}$ and subjected to LAM-PCR. The sequence information for primers is listed in Additional file 1: Table S2.

\section{Replication assay}

To evaluate the production of functional virion from RAL-treated cells, $1 \times 10^{5}$ MT- 4 cells were infected with replication-competent NL4-3 or NL-IN-D64A (20 ng p24). After $2 \mathrm{~h}$ of the infection, cells were washed with phosphate buffered saline (PBS) twice and suspended in $1.0 \mathrm{~mL}$ of medium. To prepare the culture supernatant, three-quarter of the cultures were harvested every $2 \mathrm{~d}$, and the culture was continued by adding $750 \mu \mathrm{L}$ of the complete medium into each well. From -1 dpi to harvest, MT-4 cells were treated with $10 \mu \mathrm{M}$ RAL or DMSO. Conditioned medium $(100 \mu \mathrm{L})$ was added to $1 \times$ $10^{4}$ MAGIC5 cells [28], and at $48 \mathrm{hpi}$, cells were stained by X-gal to estimate the number of transduced cells. To estimate HIV-1 RNA copy numbers, $1 \times 10^{5} \mathrm{MDMs}$ were infected with NL-ADA, NL-ADA-R(-), NL-ADAIN-D64A, or NL-ADA-IN-D64A-R(-) (20 ng p24) for 2 $\mathrm{h}$, then washed with medium four times. Three-quarters of the conditioned medium was harvested and replaced with fresh medium every $2 \mathrm{~d}$. From -1 dpi to harvest, MDMs were treated with $10 \mu \mathrm{M}$ RAL or DMSO. HIV-1 RNA of conditioned medium was purified and subjected to RT-qPCR using the Lenti-X qRT-PCR Titration Kit (TaKaRa). To evaluate the effect of DNA damaging agents, $2.5 \mu \mathrm{M}$ etoposide or $1.25 \mu \mathrm{M}$ bleomycin were added to MDMs from 0-2 dpi. To exclude a possibility that detected HIV RNA merely reflect the RNA from carry-over virion, fusion inhibitor ENF, dissolved in phosphate buffer saline PBS, was added from 0 hpi to harvest as a negative control.

\section{Colony formation assay}

To evaluate the effect of DNA damaging agents on the integration rate of D64A mutant virus, serum-starved HT1080 cells $\left(5 \times 10^{5}\right.$ cells $)$ in DMEM with $0.1 \%$ FBS were infected with a neomycin-resistant marker expressing VSVG-pseudotyped NL-Neo-IN-D64A-E(-) $\mathrm{R}(-)$ virus (100 ng p24) in the presence of 0 (DMSO), $0.625,1.25$, or $2.5 \mu \mathrm{M}$ etoposide and 0 (water), 0.313 , 0.625 , or $1.25 \mu \mathrm{M}$ bleomycin. Cells were selected with G418 from 2 dpi, then stained with Giemsa at $12 \mathrm{dpi}$. The G418-resistant colony numbers were normalized by plating efficiency, which represented the cytotoxicity of etoposide and bleomycin. The plating efficiencies after treatment of etoposide and bleomycin at 0, 0.625, $1.25,2.5 \mu \mathrm{M}$ were $100,57.2,26.0$ and $19.5 \%$, and 100 , $60.4,68.8$ and $60.4 \%$, respectively.

\section{Immunohistochemical analysis}

Detection of phosphorylated histone $\mathrm{H} 2 \mathrm{AX}(\gamma \mathrm{H} 2 \mathrm{AX})$ and phosphorylated ATM (pATM) was done, according to the reported method using antibodies against $\gamma \mathrm{H} 2 \mathrm{AX}$ (phosphorylated at Ser 139, Millipore, cat no. 05-636) and pATM (Ser 1981, Millipore, cat. no. 05-740) [37]. 
Briefly, the cells were washed with PBS and fixed with 4\% paraformaldehyde in PBS. The fixed cells were permeabilized with $0.2 \%$ Triton X-100 in PBS. After treatment with PBS supplemented with $10 \%$ goat serum for $30 \mathrm{~min}$, the cells were incubated with antibodies. After $1 \mathrm{~h}$ of incubation at $37^{\circ} \mathrm{C}$, secondary antibodies conjugated with Alexa 546 (Molecular Probes) were added for $1 \mathrm{~h}$ at $37^{\circ} \mathrm{C}$. Nuclei were stained by Hoechst33258.

\section{Luciferase assay}

To evaluate the infectivity of viruses, $1.0 \times 10^{4}$ cells were infected with VSVG-pseudotyped luciferase viruses (2 ng p24) for $48 \mathrm{~h}$, then subjected to luciferase assay by using One-Glo (Promega) and a Veritas Microplate luminometer (TURNER BIOSYSTEMS).

\section{Flow cytometry}

To analyze the status of cell cycle, HT1080 cells were labeled with $5 \mu \mathrm{M}$ BrdU for $30 \mathrm{~min}$ and fixed in ice-cold $70 \%$ ethanol. Anti-BrdU-fluorescein (Roche Diagnostics) was used to stain the BrdU-labeled cells, according to the manufacturer's instructions. BrdU-labeled cells were analyzed by BD FACSCalibur flow cytometer (BD Biosciences). To analyze the percentages of EGFPpositive cells, Flow cytometry analysis was performed using a BD FACSCalibur.

\section{FISH analysis}

Metaphase FISH analysis was performed to estimate the proviral DNA copy number and co-localization of proviral DNA and rDNA using lentiviral vector and rDNA specific probes (Chromosome Science Labo Inc.).

\section{Statistical analysis}

Statistical significance was determined by Student's $t$ test, and values of $P<0.05$ were considered statistically significant.

\section{Additional file}

Additional file 1: Figure S1. Southern blot analysis to verify the cleavage of the I-Scel and I-Ppol site. Figure S2. A schematic of the strand transfer of HIV-1 DNA to genomic DNA. Figure S3. Evaluation of lentiviral infectivity and cell cycle status of serum starved HT1080 cells by BrdU incorportion. Figure S4. Raw data in Figure 3. Figure S5. The percentage of insertion and/or deletion (InDel) mutations at the host/ viral junction. Figure S6. Two additional independent data sets in Figure $5 B$ and 5 C. Figure S7. RAL in $2 d$ cultured conditioned medium is active. Figure S8. Additinoal data sets with another donor in Figure 7D. Figure S9. Raw data in Figure 7E. Table S1. RAL and EVG resistant mutations reported in literature. Table S2. List of primers and probes used in this study. Supplementary methods. Southern blot analysis.

\section{Competing interests}

The authors declare no competing financial interests.

\section{Authors' contributions}

TK and BS designed and performed the work, analyzed the data and wrote the paper. KT and MT contributed reagents and technical advice for the work, and edited the manuscript. Yl conceived of the study and supervised the work and wrote the paper. All authors read and approved the final manuscript.

\section{Acknowledgements}

We thank Dr. F. Graham (McMaster University, Canada) for the I-Sce adenovirus vector, Dr. I. Saito (Tokyo University, Japan) for AxCALac8, Dr. M. O'Connor (KuDOS Pharmaceuticals, England) for KU55933, and Dr. M. B. Kastan (Duke Cancer Institute, USA) for pBABE-HA-ER-I-Ppol. This work was supported by a Grant-in-Aid for Research on HIV/AIDS from the Ministry of Health, Labor, and Welfare of Japan.

\section{Author details}

'Department of Intractable Diseases, National Center for Global Health and Medicine, 1-21-1 Toyama, Shinjuku-ku, Tokyo 162-8655, Japan. ${ }^{2}$ Research Group of HIV Molecular Epidemiology and Virology, The State Key Laboratory of Virology, Wuhan Institution of Virology, Chinese Academy of Sciences, Wuhan, Hubei 430071, China. ${ }^{3}$ Department of Pathology, National Institute of Infectious Diseases, 1-23-1 Toyama, Shinjuku-ku, Tokyo 162-8640, Japan. ${ }^{4}$ AIDS Research Center, National Institute of Infectious Diseases, 1-23-1

Toyama, Shinjuku-ku, Tokyo 162-8640, Japan.

Received: 26 June 2012 Accepted: 11 February 2013

Published: 21 February 2013

\section{References}

1. Perelson AS, Essunger $P$, Cao $Y$, Vesanen M, Hurley A, Saksela K, Markowitz M, Ho DD: Decay characteristics of HIV-1-infected compartments during combination therapy. Nature 1997, 387:188-191.

2. Richman DD, Margolis DM, Delaney M, Greene WC, Hazuda D, Pomerantz RJ: The challenge of finding a cure for HIV infection. Science 2009, 323:1304-1307.

3. Hazuda DJ, Felock P, Witmer M, Wolfe A, Stillmock K, Grobler JA, Espeseth A Gabryelski L, Schleif W, Blau C, Miller MD: Inhibitors of strand transfer that prevent integration and inhibit HIV-1 replication in cells. Science 2000, 287:646-650.

4. Dorr P, Westby M, Dobbs S, Griffin P, Irvine B, Macartney M, Mori J, Rickett G, Smith-Burchnell C, Napier C, et al: Maraviroc (UK-427,857), a potent, orally bioavailable, and selective small-molecule inhibitor of chemokine receptor CCR5 with broad-spectrum anti-human immunodeficiency virus type 1 activity. Antimicrob Agents Chemother 2005, 49:4721-4732.

5. Jager S, Cimermancic P, Gulbahce N, Johnson JR, McGovern KE, Clarke SC, Shales M, Mercenne G, Pache L, Li K, et al: Global landscape of HIV-human protein complexes. Nature 2012, 481:365-370.

6. Engelman A, Mizuuchi K, Craigie R: HIV-1 DNA integration: mechanism of viral DNA cleavage and DNA strand transfer. Cell 1991, 67:1211-1221.

7. Engelman A, Craigie R: Identification of conserved amino acid residues critical for human immunodeficiency virus type 1 integrase function in vitro. J Virol 1992, 66:6361-6369.

8. Brin E, Yi J, Skalka AM, Leis J: Modeling the late steps in HIV-1 retroviral integrase-catalyzed DNA integration. J Biol Chem 2000, 275:39287-39295.

9. Daniel R, Katz RA, Skalka AM: A role for DNA-PK in retroviral DNA integration. Science 1999, 284:644-647.

10. Smith JA, Wang FX, Zhang H, Wu KJ, Williams KJ, Daniel R: Evidence that the Nijmegen breakage syndrome protein, an early sensor of doublestrand DNA breaks (DSB), is involved in HIV-1 post-integration repair by recruiting the ataxia telangiectasia-mutated kinase in a process similar to, but distinct from, cellular DSB repair. Virol J 2008, 5:11

11. Kameoka M, Nukuzuma S, Itaya A, Tanaka Y, Ota K, Ikuta K, Yoshihara K: RNA interference directed against Poly(ADP-Ribose) polymerase 1 efficiently suppresses human immunodeficiency virus type 1 replication in human cells. J Virol 2004, 78:8931-8934.

12. Daniel R, Marusich E, Argyris E, Zhao RY, Skalka AM, Pomerantz RJ: Caffeine inhibits human immunodeficiency virus type 1 transduction of nondividing cells. J Virol 2005, 79:2058-2065.

13. Daniel R, Katz RA, Merkel G, Hittle JC, Yen TJ, Skalka AM: Wortmannin potentiates integrase-mediated killing of lymphocytes and reduces the efficiency of stable transduction by retroviruses. Mol Cell Biol 2001, 21:1164-1172. 
14. Lau A, Swinbank KM, Ahmed PS, Taylor DL, Jackson SP, Smith GC, O'Connor MJ: Suppression of HIV-1 infection by a small molecule inhibitor of the ATM kinase. Nat Cell Biol 2005, 7:493-500.

15. Sakurai $Y$, Komatsu K, Agematsu K, Matsuoka M: DNA double strand break repair enzymes function at multiple steps in retroviral infection. Retrovirology 2009, 6:114.

16. Siva AC, Bushman F: Poly(ADP-ribose) polymerase 1 is not strictly required for infection of murine cells by retroviruses. J Virol 2002, 76:11904-11910.

17. Dehart $J$, Andersen JL, Zimmerman ES, Ardon O, An DS, Blackett J, Kim $B$, Planelles $\mathrm{V}$ : The ataxia telangiectasia-mutated and Rad3-related protein is dispensable for retroviral integration. J Virol 2005, 79:1389-1396.

18. Baekelandt V, Claeys A, Cherepanov P, De Clercq E, De Strooper B, Nuttin B, Debyser Z: DNA-Dependent protein kinase is not required for efficient lentivirus integration. J Virol 2000, 74:11278-11285.

19. Ariumi $Y$, Turelli $P$, Masutani $M$, Trono D: DNA damage sensors ATM, ATR, DNA-PKcs, and PARP-1 are dispensable for human immunodeficiency virus type 1 integration. J Virol 2005, 79:2973-2978.

20. Bauer M, Goldstein M, Christmann M, Becker H, Heylmann D, Kaina B: Human monocytes are severely impaired in base and DNA doublestrand break repair that renders them vulnerable to oxidative stress. Proc Natl Acad Sci USA 2011, 108:21105-21110.

21. Tsuchiya S, Kobayashi Y, Goto Y, Okumura H, Nakae S, Konno T, Tada K: Induction of maturation in cultured human monocytic leukemia cells by a phorbol diester. Cancer Res 1982, 42:1530-1536.

22. Anglana $M$, Bacchetti S: Construction of a recombinant adenovirus for efficient delivery of the I-Scel yeast endonuclease to human cells and its application in the in vivo cleavage of chromosomes to expose new potential telomeres. Nucleic Acids Res 1999, 27:4276-4281.

23. Berkovich E, Monnat RJ Jr, Kastan MB: Roles of ATM and NBS1 in chromatin structure modulation and DNA double-strand break repair. Nat Cell Biol 2007, 9:683-690.

24. Matsuo M, Kaji K, Utakoji T, Hosoda K: Ploidy of human embryonic fibroblasts during in vitro aging. J Gerontol 1982, 37:33-37.

25. Skalka AM, Katz RA: Retroviral DNA integration and the DNA damage response. Cell Death Differ 2005, 12(Suppl 1):971-978.

26. Perez EE, Wang J, Miller JC, Jouvenot Y, Kim KA, Liu O, Wang N, Lee G, Bartsevich $W$, Lee $Y$ L, et al: Establishment of HIV-1 resistance in CD4+ T cells by genome editing using zinc-finger nucleases. Nat Biotechnol 2008, 26:808-816.

27. Schmidt M, Schwarzwaelder K, Bartholomae C, Zaoui K, Ball C, Pilz I, Braun S, Glimm H, von Kalle C: High-resolution insertion-site analysis by linear amplification-mediated PCR (LAM-PCR). Nat Methods 2007, 4:1051-1057.

28. Mochizuki N, Otsuka N, Matsuo K, Shiino T, Kojima A, Kurata T, Sakai K, Yamamoto N, Isomura S, Dhole TN, et al: An infectious DNA clone of HIV type 1 subtype C. AIDS Res Hum Retroviruses 1999, 15:1321-1324.

29. McColl DJ, Chen X: Strand transfer inhibitors of HIV-1 integrase: bringing IN a new era of antiretroviral therapy. Antiviral Res 2010, 85:101-118.

30. Mouscadet JF, Delelis O, Marcelin AG, Tchertanov L: Resistance to HIV-1 integrase inhibitors: a structural perspective. Drug Resist Updat 2010, 13:139-150.

31. Serrao E, Odde S, Ramkumar K, Neamati N: Raltegravir, elvitegravir, and metoogravir: the birth of "me-too" HIV-1 integrase inhibitors. Retrovirology 2009, 6:25

32. Shafer RW, Schapiro JM: HIV-1 drug resistance mutations: an updated framework for the second decade of HAART. AIDS Rev 2008, 10:67-84.

33. Baydoun HH, Bai XT, Shelton S, Nicot C: HTLV-I tax increases genetic instability by inducing DNA double strand breaks during DNA replication and switching repair to NHEJ. PLOS One 2012, 7:e42226.

34. Matsuoka M, Jeang KT: Human T-cell leukemia virus type 1 (HTLV-1) and leukemic transformation: viral infectivity, Tax. HBZ and therapy. Oncogene 2011, 30:1379-1389.

35. Malim MH, Emerman M: HIV-1 accessory proteins-ensuring viral survival in a hostile environment. Cell Host Microbe 2008, 3:388-398.

36. Nakai-Murakami C, Shimura M, Kinomoto M, Takizawa Y, Tokunaga K, Taguchi T, Hoshino S, Miyagawa K, Sata T, Kurumizaka H, et al: HIV-1 Vpr induces ATM-dependent cellular signal with enhanced homologous recombination. Oncogene 2007, 26:477-486.

37. Tachiwana H, Shimura M, Nakai-Murakami C, Tokunaga K, Takizawa Y, Sata T, Kurumizaka H, Ishizaka Y: HIV-1 Vpr induces DNA double-strand breaks. Cancer Res 2006, 66:627-631.
38. Roshal M, Kim B, Zhu Y, Nghiem P, Planelles V: Activation of the ATRmediated DNA damage response by the HIV-1 viral protein R. J Biol Chem 2003, 278:25879-25886.

39. Daniel R, Kao G, Taganov K, Greger JG, Favorova O, Merkel G, Yen TJ, Katz RA, Skalka AM: Evidence that the retroviral DNA integration process triggers an ATR-dependent DNA damage response. Proc Natl Acad Sci USA 2003, 100:4778-4783.

40. Belzile JP, Richard J, Rougeau N, Xiao Y, Cohen EA: HIV-1 Vpr induces the K48-linked polyubiquitination and proteasomal degradation of target cellular proteins to activate ATR and promote G2 arrest. J Virol 2010, 84:3320-3330

41. Nakai-Murakami C, Minemoto $Y$, Ishizaka $Y$ : Vpr-induced DNA doublestrand breaks: molecular mechanism and biological relevance. Curr HIV Res 2009, 7:109-113.

42. Taneichi D, lijima K, Doi A, Koyama T, Minemoto $Y$, Tokunaga K, Shimura M, Kano S, Ishizaka Y: Identification of SNF2h, a chromatin-remodeling factor, as a novel binding protein of Vpr of human immunodeficiency virus type 1. J Neuroimmune Pharmacol 2011, 6:177-187.

43. Connor Rl, Chen BK, Choe S, Landau NR: Vpr is required for efficient replication of human immunodeficiency virus type-1 in mononuclear phagocytes. Virology 1995, 206:935-944.

44. Smith JA, Daniel R: Up-regulation of HIV-1 transduction in nondividing cells by double-strand DNA break-inducing agents. Biotechnol Lett 2011, 33:243-252.

45. Leavitt AD, Robles G, Alesandro N, Varmus HE: Human immunodeficiency virus type 1 integrase mutants retain in vitro integrase activity yet fail to integrate viral DNA efficiently during infection. J Virol 1996, 70:721-728.

46. Nakajima N, Lu R, Engelman A: Human immunodeficiency virus type 1 replication in the absence of integrase-mediated dna recombination: definition of permissive and nonpermissive T-cell lines. J Virol 2001, 75:7944-7955

47. Gaur M, Leavitt AD: Mutations in the human immunodeficiency virus type 1 integrase $D, D(35) E$ motif do not eliminate provirus formation. J Virol 1998, 72:4678-4685.

48. Ebina $H$, Kanemura $Y$, Suzuki $Y$, Urata $K$, Misawa N, Koyanagi $Y$ : Integraseindependent HIV-1 infection is augmented under conditions of DNA damage and produces a viral reservoir. Virology 2012, 427:44-50.

49. Miller DG, Petek LM, Russell DW: Adeno-associated virus vectors integrate at chromosome breakage sites. Nat Genet 2004, 36:767-773.

50. Bill CA, Summers J: Genomic DNA double-strand breaks are targets for hepadnaviral DNA integration. Proc Natl Acad Sci USA 2004, 101:11135-11140.

51. Moore JK, Haber JE: Capture of retrotransposon DNA at the sites of chromosomal double-strand breaks. Nature 1996, 383:644-646.

52. Farkash EA, Kao GD, Horman SR, Prak ET: Gamma radiation increases endonuclease-dependent $\mathrm{L} 1$ retrotransposition in a cultured cell assay. Nucleic Acids Res 2006, 34:1196-1204.

53. Masuda T, Planelles $V$, Krogstad P, Chen IS: Genetic analysis of human immunodeficiency virus type 1 integrase and the U3 att site: unusual phenotype of mutants in the zinc finger-like domain. J Virol 1995, 69:6687-6696

54. Wu Y, Marsh JW: Selective transcription and modulation of resting T cell activity by preintegrated HIV DNA. Science 2001, 293:1503-1506.

55. Engelman A, Englund G, Orenstein JM, Martin MA, Craigie R: Multiple effects of mutations in human immunodeficiency virus type 1 integrase on viral replication. J Virol 1995, 69:2729-2736.

56. Poon B, Chang MA, Chen IS: Vpr is required for efficient Nef expression from unintegrated human immunodeficiency virus type 1 DNA. J Virol 2007, 81:10515-10523.

57. Fouchier RA, Meyer BE, Simon JH, Fischer U, Malim MH: HIV-1 infection of non-dividing cells: evidence that the amino-terminal basic region of the viral matrix protein is important for Gag processing but not for postentry nuclear import. EMBO J 1997, 16:4531-4539.

58. Adachi A, Gendelman HE, Koenig S, Folks T, Willey R, Rabson A, Martin MA Production of acquired immunodeficiency syndrome-associated retrovirus in human and nonhuman cells transfected with an infectious molecular clone. J Virol 1986, 59:284-291.

59. Tokunaga K, Greenberg ML, Morse MA, Cumming RI, Lyerly HK, Cullen BR: Molecular basis for cell tropism of CXCR4-dependent human immunodeficiency virus type 1 isolates. J Virol 2001, 75:6776-6785.

60. Mizoguchi I, Ooe Y, Hoshino S, Shimura M, Kasahara T, Kano S, Ohta T, Takaku F, Nakayama Y, Ishizaka Y: Improved gene expression in resting macrophages using an oligopeptide derived from $\mathrm{Vpr}$ of human 
immunodeficiency virus type-1. Biochem Biophys Res Commun 2005, 338:1499-1506.

61. Hoshino S, Konishi M, Mori M, Shimura M, Nishitani C, Kuroki Y, Koyanagi Y, Kano S, Itabe H, Ishizaka Y: HIV-1 Vpr induces TLR4/MyD88-mediated IL-6 production and reactivates viral production from latency. J Leukoc Biol 2010, 87:1133-1143

62. Iwabu Y, Fujita H, Kinomoto M, Kaneko K, Ishizaka Y, Tanaka Y, Sata T, Tokunaga K: HIV-1 accessory protein Vpu internalizes cell-surface BST-2 /tetherin through transmembrane interactions leading to lysosomes. J Biol Chem 2009, 284:35060-35072.

63. Iwabu Y, Kinomoto M, Tatsumi M, Fujita H, Shimura M, Tanaka Y, Ishizaka Y, Nolan D, Mallal S, Sata T, Tokunaga K: Differential anti-APOBEC3G activity of HIV-1 Vif proteins derived from different subtypes. J Biol Chem 2010, 285:35350-35358.

64. Butler SL, Hansen MS, Bushman FD: A quantitative assay for HIV DNA integration in vivo. Nat Med 2001, 7:631-634.

65. Yamamoto N, Tanaka C, Wu Y, Chang MO, Inagaki Y, Saito Y, Naito T, Ogasawara H, Sekigawa I, Hayashida Y: Analysis of human immunodeficiency virus type 1 integration by using a specific, sensitive and quantitative assay based on real-time polymerase chain reaction. Virus Genes 2006, 32:105-113.

66. Schmidt M, Zickler P, Hoffmann G, Haas S, Wissler M, Muessig A, Tisdale JF, Kuramoto K, Andrews RG, Wu T, et al: Polyclonal long-term repopulating stem cell clones in a primate model. Blood 2002, 100:2737-2743.

doi:10.1186/1742-4690-10-21

Cite this article as: Koyama et al:: DNA damage enhances integration of HIV-1 into macrophages by overcoming integrase inhibition.

Retrovirology 2013 10:21.

\section{Submit your next manuscript to BioMed Central and take full advantage of:}

- Convenient online submission

- Thorough peer review

- No space constraints or color figure charges

- Immediate publication on acceptance

- Inclusion in PubMed, CAS, Scopus and Google Scholar

- Research which is freely available for redistribution 